\title{
Brazil's best university seeks fame
}

\section{The University of São Paulo believes it should be making a more prominent mark on the world outside Brazil, but the difficulties of doing so from within a still-developing country are greater and less tangible than may be thought.}

São Paulo. This city, the traffic-jam capital of the world, may not be the whole of Brazil, but it is more than 10 per cent of it in terms of population, while the state of which the city is the capital earns roughly half of Brazil's gross national product and is home to half of Brazil's research.

An industrial city, São Paulo has managed to keep many patches of elegance and greenery among the high-rise buildings and football stadia; the cardboard slums are inconspicuously on the periphery. The city also houses the largest of the University of São Paulo's five campuses, with some 30,000 undergraduates on the site.

Like universities throughout Brazil, the University of São Paolo (USP) is a young institution - and looks and feels like that. It was formed only in 1934, around pre-existing and free-standing schools of law, engineering and medicine. Unlike others among Brazil's universities that are known elsewhere, São Paulo is proudly and advantageously a child of the state government, whose constitution requires that a fixed proportion (about 9 per cent) of its revenues should be spent on higher education.

Once that cake is cut each year - the other chief beneficiary is the University of Campinas - the university is financially autonomous, but the new vice-rector wistfully observes that 85 per cent of the state's contribution to the annual budget goes on salaries, and much of the remainder on heat, light and the like. Research is financed separately, partly by contracts with government agencies or industrial companies (multinational rather than Brazilian) and partly by means of competitive research grants from the state-run research foundation whose budget is again a fixed proportion (roughly 1 per cent) of the state's spending.

Never have academics sung so warmly the praises of a state-run research foundation as this university's do for the state of São Paulo's research foundation, FASESP. Five years appear not to have abated admiration for the foundation's way of working (see Nature 342, 372; 1989). The foundation works quickly, using academics rather than paid officials to make decisions, decisions are respected even by those who are refused funds and hardly any of the $\$ 100$ million a year is spent on administration. By comparison, getting funds out of the national research foundations is like pulling paper tissues out of a water-soaked box. And the São Paulo campus of USP reckons routinely to capture half the total.
So why does this university, by general agreement the best in Brazil, have a palpable sense of disappointment at its standing among the world's universities? "Tell us why", demanded one of half a dozen physicists last week, "you think that São Paulo is the best?" References to São Paulo's predominance among the trickle of Brazilian submissions to this journal, and to the frequency with which Brazilian visitors elsewhere turn out to be from this university, fail to convince. The university would give its eye-teeth for a reputation for excellence in some field.

It is a curious dilemma. Brazil is hardly a typical developing country. As in India, of course, there is a cruel contrast between the rich (some of whom are seriously rich) and the poor. But, by contrast with India, academics seem united in holding that the poor must quickly be made prosperous. (One of them, Professor Isaias Raw, director of the Butantan biotechnology centre, distinct from but adjacent to the São Paulo campus, says that Brazil owes this duty even to the primitive Indian communities of Amazonia.)

So whence the vague sense of isolation? Not isolation from the Internet, certainly. Those who are so inclined can hook up as easily as anywhere, and proudly proclaim their e-mail addresses on the name-cards. (The suffix ".usp.br" will get you to São Paulo.) Nor can it be that active researchers fail to attend meetings overseas. São Paulo's research foundation is generous with travel grants. And most people's English is excellent, while the Latin roots of Portuguese are easily recognizable.

Part of the explanation is historical, and recently so. The long period of military rule (between 1962 and 1982, with a kind of transitional period until 1985) has scarred the universities. It is not simply that many able people were forced out of their jobs (Isaias Raw first read of his dismissal in the newspaper), but that those left behind in the departments were induced by fear not to make difficulties of any kind, among which over-intimacy with the world elsewhere could easily have been one.

This was also a period in which the military government embarked on nuclear and space research programmes quite separately from the academic community. This is when, according to one last week, the academic community in Brazil as a whole "was isolated from the people". The political turmoil of the Collor presidency, brought prematurely to an end two years ago by charges of embezzlement, has not helped.
The university's own constitution is a further difficulty. All academics are tenured. Autonomous though the university may be, while those who have tenure and no great zeal for research are in the majority, São Paulo will be struggling to build depth around its research programmes. There are further problems about appointments; departments recommend the appointment of new recruits, but the university has the last word and does not always grant departments' wishes.

Even so, tough questions are being asked. An evaluation of all 70-odd departments and institutes has been mounted. There is also a project to define what is meant by a "department" that promises more radical criteria for the future division of the university's income; São Paulo seems on the way to rediscovering the general rule that the smaller a department, the more expensive and less productive it tends to be.

The more serious difficulties are to do with questions of critical mass. Active parts of the university are excellently equipped, while academics are well (if too uniformly) paid. (Salaries range from US $\$ 1,500$ to $\$ 5,000$ a month, including a federal supplement of the salaries of senior people.) The physics department boasts of no fewer than 17 buildings, enclosing a splendid lowtemperature facility and a small tokamak, for example. But there is rarely a great enough concentration of people in one field of research to keep up with the furious pace of discovery elsewhere in the world.

Walter Colli, director of the Institute of Chemistry, sees the problem clearly. The institute has enough people to make a mark. By concentrating on fields such as protein structure/function relations, the physiological role of free radicals and chiral organic synthesis, he plans that those concerned should make their mark within the coming 15 years. It is a brave hope, but one echoed by many others at São Paulo last week.

Isaias Raw is in a greater hurry. The Butantan Institute was meant, at its foundation in 1901, to be Brazil's equivalent of the Pasteur Institute. Since 1985, it has been a biotechnology centre as well, but has had to recreate the technology of making snakevenom antisera. If, after the general election this week, Brazil adopts a law conferring patent rights on biotechnology processes developed elsewhere, Raw will have only a 12-month grace period in which to develop Brazil's equivalents. It may be true, as one academic put it last week, that "Brazil is too big to be a small country", but old habits die hard.

John Maddox 